\title{
Industry-wide work rules and productivity: evidence from Argentine union contract data
}

\author{
Carlos Lamarche
}

\section{Correspondence:}

clamarche@uky.edu

University of Kentucky and IZA,

335A Gatton Business and

Economics BLDG, Gatton School of

Business, Lexington, KY 40506-0034, USA

\section{Springer}

\begin{abstract}
In the early 1990's, the Argentine government promoted a framework for productivity-based negotiations between firms and unions at low levels of organization. The policy weakened the industry-wide collective bargaining system, which sets working conditions for all firms in an industry. This paper employs newly developed quantile regression approaches to investigate the effect of union practices on productivity within the context of the reform. The findings show that (i) industry-wide practices on displacement of workers and training have a negative impact on productivity; (ii) work practices do not appear to restrict economic efficiency in the post-reform period; (iii) union practices on technology acquisition have an adverse effect on high-productivity growth industries. Productivity seems to improve in an economy promoting policies to weaken industry-wide collective bargaining.
\end{abstract}

JEL codes: J52; $\mathrm{O} 14 ; \mathrm{O} 43 ; \mathrm{O} 54$

Keywords: Work practices; Productivity; Manufacturing; Quantile regression

\section{Introduction}

Latin American economies are known for offering disappointing evidence in terms of development. Argentina is a leading example of an economy falling behind the United States and other Western world economies in the last half century. Although existing theories offer different explanations, a conventional view focuses on government policies restricting competition and efficiency. Industry-wide work rules may be seen within this view, because they set working conditions for heterogeneous firms in an industry at a regional or national level. Thus, unions might generate inefficiencies associated with restrictive work practices, having a negative impact on productivity. This paper offers industry-level evidence that in an economy promoting policies to weaken industry-wide collective bargaining, labor productivity in manufacturing improves.

Argentina's labor market reforms in the early 1990's invite an opportunity for estimating the effect of work practices on productivity. For decades, labor market institutions had responded to a monopolistic (state-sanctioned) protection of unions by sectors, centralized bargaining including industry-wide work rules, and union contracts of indefinite duration (Etchemendy 2001, O'Connell 1999). During the 1970's and 1980's, contracts signed by industry had been dominating contracts signed by firms leading to what is best known as industry-wide work rules. The hierarchy of contracts could have important implications for efficiency and management's ability to organize production since

(02013 Lamarche; licensee Springer. This is an Open Access article distributed under the terms of the Creative Commons

Attribution License (http://creativecommons.org/licenses/by/2.0), which permits unrestricted use, distribution, and reproduction in any medium, provided the original work is properly cited. 
industry-wide agreements include binding standards applied throughout the industry. Since the reforms in the early 1990's, the government implemented policies promoting firm-level collective agreements that were bargained at low levels of organization (Tuman and Morris 1998). This includes a decentralization framework for collective bargaining and negotiations based on productivity. Although the reforms were in practice only partially effective, they affected industrial relations in the manufacturing sector. For instance, several contracts in the automobile industry were limited to the utilization of high quality production techniques.

Our identification strategy is based on the comparison of manufacturing industries whose workers are covered by contracts bargained after the reforms and industries whose workers are covered by contracts bargained before the reforms, when unions played a major role at the industry and national level. It is naturally challenging to investigate how work practices including rules on technology acquisition affect productivity levels and growth, but the exercise should offer a credible measure of the effect of industrywide work rules. First, the policy change should be perceived as exogenous relative to the manufacturing industries because the reforms were part of Argentina's market-oriented structural reforms that include a liberalization program, privatized public enterprises, and measures to deregulate the economy. Second, it is possible to find work rules that were bargained between firms and unions from samples of collective agreements signed before and after the labor reforms. We develop a unique union contract data set that includes union practices on capital acquisition affecting manufacturing firms located in different states. To the best of our knowledge, our study is the first one that uses union contract data in a developing country to examine the effect of work practice changes on productivity.

Although the reform may be considered to be exogenous, work practices are suspected to be endogenous because unions and firms bargain on practices and productivity after the reforms. In order to investigate this possibility empirically, we employ classical instrumental variable approaches for estimating a difference-in-difference model. The specification includes industry effects and state effects. To instrument a work rule bargained in an industry located in a state, we use length of contracts and number of employees covered by union contracts in other industries located in other states. These instruments capture variation created by the reforms that is not related to productivity advances in the industry. The sets of instruments pass standard tests used by practitioners in all the specifications. The evidence shows that industry-wide practices on displacement of workers and capital acquisition have a negative impact on productivity. However, in the period after the reforms, union practices do not appear to restrict economic efficiency. This evidence might be interpreted as suggesting that policies designed to weaken the industry-wide collective agreements increased firm's efficiency in the manufacturing sector.

A recent body of the literature investigates the distributional effect of policy (see, e.g., Bandiera et al. 2010, Bitler et al. 2006). While the empirical literature traditionally has focused upon estimating how unions affect mean productivity, this approach may be incomplete if industry-wide rules do not similarly impact low- and high-productivity industries. As in Bandiera et al. 2010, we model heterogeneity of effects throughout a quantile regression model. We can use instrumental variable and panel data quantile regression approaches to estimate the models (Chernozhukov and Hansen (2006, 2008), Harding and Lamarche 2009, Koenker 2004). Existing methods, however, are 
not well suited for investigating the effect of practices on our productivity equation. We simply accommodate the approaches proposed in Koenker (2004) and Harding and Lamarche (2009) to estimate the distributional effect of work practices on the conditional response distribution. We find that practices on capital acquisition have a small negative impact at the lower tail of the conditional productivity growth distribution, suggesting that this practice has a modest negative effect on low-productivity growth industries. On the other hand, practices on technology acquisition seem to have an adverse effect on high-productivity growth industries, decreasing productivity by $6.7 \%$. The results for the period post-reform suggest that productivity growth improves $3.6 \%$ under weakened industry-wide practices on the incorporation of new technology.

Union practices affecting economic efficiency have received extensive attention from theorists and applied economists. Theoretical support for the effect of working rules on aggregate output growth is given by Holmes and Schmitz (1995), Parente and Prescott (1999, 2000), Prescott (1998), Cole et al. (2005), and Bental and Demougin (2006). Holmes and Schmitz (1995) show that better technology is not adopted in an economy where workers have some degree of monopoly power. Prescott (1998) argues that work practices affect economic efficiency. In Parente and Prescott (1999), the coalition of factor suppliers set work practices and wages, and make it difficult to enter the market with a more productive technology. Inferior technologies are used, and consequently there is less growth in output. Cole et al. (1999) argue that international and domestic competitive barriers explain why Latin America economies have not followed Western economies success.

The large existing empirical evidence is controversial. The literature reports positive and negative overall union productivity effects consistent with the fact that unions have two "faces". Freeman and Medoff (1984) initiated a debate by pointing out that potential increases in productivity are induced by unions that provide workers a collective voice in the workplace. In contrast, unions may reduce productivity by reallocation and inefficiency associated with restrictive work rules (Bremmels 1987). ${ }^{1}$ The mixed empirical evidence of the effect of unions on productivity covers a variety of industries including manufacturing, construction, and services in the United States and United Kingdom. A few papers, notably Ferreira and Rossi (2003) and Galiani and Sturzenegger (2008), have studied the effect of unions in Latin America. Our empirical approach, that uses data before and after a policy change, is similar to the one used in Ferreira and Rossi (2003).

The outline of the paper is as follows. Section 2 introduces a theoretical framework. Section 3 presents institutional details and describes the union contract data set constructed in this paper. While Section 4 briefly presents models and methods, Section 5 presents empirical results. Section 6 concludes.

\section{A simple modeling framework}

This section presents a framework following the literature on unionization structures and incentives to adopt new technology. We develop a simple extension of the model introduced in Haucap and Wey $(2002,2004)$ to analyze the effect of industry-wide bargaining on technology adoption. Under firm-level negotiations, the union of the less efficient firm accepts working conditions to maintain the firm competitiveness in the product market. On the other hand, under industry-wide negotiations, an industry union exploits its 
monopoly power. This section shows that investment incentives which depend on how productivity enhancing technology affects firms' profit can be lower under industry-wide bargaining than under firm level bargaining.

Consider two firms $i=\{1,2\}$ in an industry $m$ producing an homogeneous product. We assume an inverse linear demand function $p=A-q_{1}-q_{2}$, with $A>q_{1}+q_{2}$. The good offered by firm $i, q_{i}$, is produced by employing labor $l_{i}$, which is the only input in the production process. Firm 1 has the opportunity of introducing an innovation that reduces the labor requirement per unit of output by $\phi$ paying a cost $c .^{2}$ The (sunk) cost of implementing the innovation, $c$, is exogenous and can be seen as measuring the severity of a hold-up problem. ${ }^{3}$ The total cost of employing one unit of labor $w_{i}$ is set by unions. The variable includes wages and other costs per unit of labor associated with working practices described in union contracts. Workers have an outside option $w_{0}$.

There are three stages in the game. In the first stage, firm 1 decides whether to implement an innovation $\phi$. In the second stage, unions set $w_{i}$ considering firm's setting their employment level $l_{i}$. Work rules including wages can be set at the industry-level by a union that maximizes the industry benefit bill $U^{I}\left(w_{i}, w_{j}\right)=\sum_{i=1}^{2} l_{i}\left(w_{i}-w_{0}\right)$. The alternative, competing structure is characterized by a union maximizing the firm's benefit bill, $U^{F}\left(w_{i}, w_{j}\right)=l_{i}\left(w_{i}-w_{0}\right)$. The solutions of these problems are denoted by $\left(w_{1}^{I}, w_{2}^{I}, w_{1}^{F}, w_{2}^{F}\right)$. Finally, in the last stage, firms compete in quantities taking productivity levels and the cost of labor as given.

The incentive to innovate $\Phi_{1}$ is defined as the profit differential between the profit of firm 1 when an innovation is implemented, $\Pi_{1}\left(w_{1}, w_{2}, \phi\right)$, and the profit of firm 1 when an innovation is not implemented, $\Pi_{1}\left(w_{1}, w_{2}, 0\right)$. Note however that the profit differential depends on the level of negotiation. We denote $\Phi_{1}^{F}$ the incentive to innovate under firmlevel negotiations and $\Phi_{1}^{I}$ the incentive to innovate under industry-level negotiations. Therefore, the value of the incentive differential $\Delta \Phi_{1}=\Phi_{1}^{I}-\Phi_{1}^{F}$ measures the incentive of implementing a labor productivity innovation under industry-wide agreements. For productivity increases $\phi<1 / 3$, it is possible to show that the incentive differential $\Delta \Phi_{1}$ is negative, implying that firm 1's incentive to adopt new technology under industry-wide collective agreements is lower than firm 1's incentive under firm-level collective agreements. An implication of this result is that industry-wide bargaining is expected to have an adverse effect on productivity, with the largest negative impact on high productivity industries. $^{4}$

\section{Collective bargaining in Argentina}

\subsection{Institutional details}

There have been no changes in the institutional features of Argentina's industrial relations in the period 1973-1990 in which its GDP per capita decreased (Figure 1). The country's traditional collective bargaining system included centralized negotiations between unions and firms affecting millions of workers. The two most important aspects of centralized negotiations were the extensive (monopolistic) protection (O'Connell 1999) and the industry-wide work rules (Bronstein 1978). Traditionally, few unions were allowed to represent workers in collective bargaining and strikes, a status called "personería gremial". Once bargaining rights have been granted to a high-level union, low-level agreements are not possible. Industry-wide practices refer to work rules introduced by high-level industry 


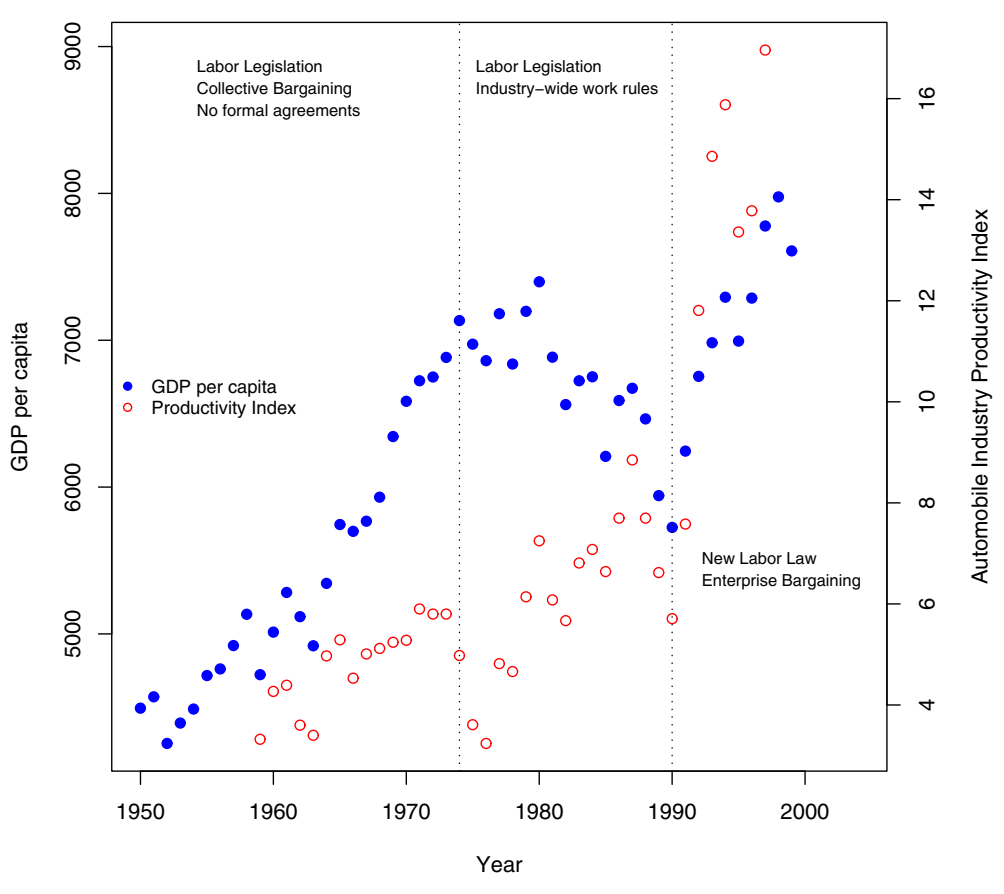

Figure 1 Argentina's per capita gross domestic product (GDP) and a productivity index in the automobile industry in the period 1950-2000. The source of the productivity index is Asociación de Fábricas de Automotores (ADEFA) and Catalano and Novick (1998).

agreements that set standards to other (lower-level) agreements. For example, if at the industry level it is established that the wage is w, firms and workers must bargain over a wage that is at least w. ${ }^{5}$

In the early 1990's, Argentina made considerable progress on implementing marketoriented structural reforms. ${ }^{6}$ The major changes in the labor market institutions were: (a) the decentralization of the negotiation process and (b) the introduction of negotiations based on productivity (Cardozo and Gindin 2009). Although the reforms and the implementation of the policies were fairly complex in nature, the agreement in the literature is that the reforms undermined the hierarchy of the traditional industry-wide collective negotiations. The government implemented policies promoting firm-level collective agreements that were bargained at low levels of organization (Tuman and Morris 1998). For instance, the decree 2284 written in 1991 indicates that unions and employers have the right to "choose the level of negotiation they consider appropriate" in new or renegotiated collective agreements. After the reforms were introduced, the number of beneficiaries per contract decreased and contracts at low levels of organization doubled in percentage.

Flexible working hours, flexible contracts and flexible organization of work were also introduced in new and renewed contracts. The collective agreements in the automobile industry, nicely described in Catalano and Novick (1998), provide an interesting and illustrative example of the changes. A number of collective agreements written in 1975 were extended without changes in the automobile industry, but other contracts were modified. For instance, the system of 8 to 10 categories agreed in 1975 was reduced to four 
occupational categories in the early 1990's. The productivity in the automobile industry increased dramatically after the introduction of the reforms (Figure 1).

\subsection{A description of the union data}

Our analysis focuses on a sample of collective agreements in the manufacturing sector in the period 1973-1994 (Table 1). Basic information about the population of union contracts in manufacturing industries can be found in Aldao-Zapiola et al. (1994). In Appendix, they offer a comprehensive list of collective agreements by rounds of negotiation that includes number of the contract and year. From this list of union contracts, we draw a sample of collective agreements after we stratify the population by rounds of negotiation. ${ }^{7}$ Subsequently, we proceed to obtain copies of the selected collective agreements. A large proportion of contracts were made available to us from the samples analyzed in Aldao-Zapiola et al. and the ones that were not available were obtained from the library of the Ministerio de Trabajo de la Nación Argentina (Argentina's Labor Department) and its website. ${ }^{8}$

A breakdown of the contracts by negotiation round is offered in Table 1. The table reports number of contracts and average number of employees covered by collective agreements. For comparative purposes, we offer information on the entire population of manufacturing contracts. It is immediately apparent than our sample includes major agreements, because 36.8 percent of contracts covers 60.7 percent of workers. Corresponding to the population trend, most contracts show sizable decline in the number of beneficiaries over time. The table also shows the proportion of renegotiated contracts. Only 10 manufacturing contracts written between 1973 and 1990 were renegotiated after the reforms were implemented in the early 1990's. It is interesting to note however that renegotiated contracts have, on average, more beneficiaries than other manufacturing contracts.

Bargaining units can be classified into four groups: establishment (plant), firm (multiplant), area and industry. Our sample of collective agreements includes industry level contracts and firm level contracts written before and after the reforms. In industry level contracts, unions and employers' associations bargain over working conditions that are

Table 1 Contracts and workers covered by collective agreements in the manufacturing industry

\begin{tabular}{lccc}
\hline \multicolumn{1}{c}{$\begin{array}{c}\text { Collective agreements in the } \\
\text { manufacturing sector }\end{array}$} & $\begin{array}{c}\text { First round } \\
\mathbf{1 9 7 3 - 1 9 7 6}\end{array}$ & $\begin{array}{c}\text { Second round } \\
\text { 1988-1990 }\end{array}$ & $\begin{array}{c}\text { Third round } \\
\text { 1991-1994 }\end{array}$ \\
\hline Total number of contracts & 218 & Entire population of union contracts \\
Workers covered by contracts & 2327859 & 983173 & 31 \\
Workers per contract & 10678 & 8549 & 203315 \\
& \multicolumn{3}{c}{ Sample of union contracts } \\
\hline Total number of contracts & 47 & 56 & 6559 \\
Workers covered by contracts & 1105640 & 824800 & 203315 \\
Workers per contract & 23524 & 14728 & 6559 \\
\hline Number of renegotiated contracts & 6 & 4 & 1 \\
Workers covered by renegotiated contracts & 213400 & 82000 & 8000 \\
Workers per renegotiated contract & 35567 & 20500 & 8000 \\
\hline Percentage of renegotiation after reforms & 12.7 & 7.1 & 3.2 \\
\hline
\end{tabular}


applied throughout the industry. In firm level contracts, a firm with multiple establishments negotiates with a national or regional union. In our sample of major union contracts, the proportion of industry contracts decreased 11 percent in the 1990's, although there was a significant reduction in the number of beneficiaries per contract that exceeded 55 percent. This last number reflects in part the weakening of the industry-wide bargaining. Industry level contracts were not restrictive in the period after the reforms, because provisions negotiated between industry unions and employers' associations were not necessarily applied to bargaining units at lower levels.

The impact of the reforms on the bargaining process can be alternatively described using the geographical coverage of the collective agreements. Their coverage is limited to a firm, a state, a number of states, or it can be national in character. In our sample of manufacturing agreements, 17 percent of the contracts are binding within a particular city, state or region. For instance, the collective agreement 167 signed in 1975 covered manufactures of quebracho extracts. ${ }^{9}$ The collective agreement covers the Argentine Chaco region including the provinces of Santiago del Estero and Santa Fe. Local agreements could also be possible by national unions with local representation and affiliation. The collective agreement of General Motors Argentina in the 1990's was signed by the union of the province of Córdoba, where the main plant of the firm is located. As shown in Figure 2, the reforms introduced in the early 1990's significantly increased the proportion of regional and firm contracts at low levels of organization, although industry bargaining remained widespread in the period after the reforms.

Using the sample of manufacturing contracts, we identify 16 commonly included practices. Work rules can be categorized into 6 groups: working conditions, redeployment, hiring and layoffs, working week, featherbedding and capital acquisition (Table 2). An example of practices on technology can be found in the collective agreement between the Union of Chemical and Petrochemicals industry and the Argentine Chamber of the Chemical and Petrochemical industry signed in 1989. The contract,
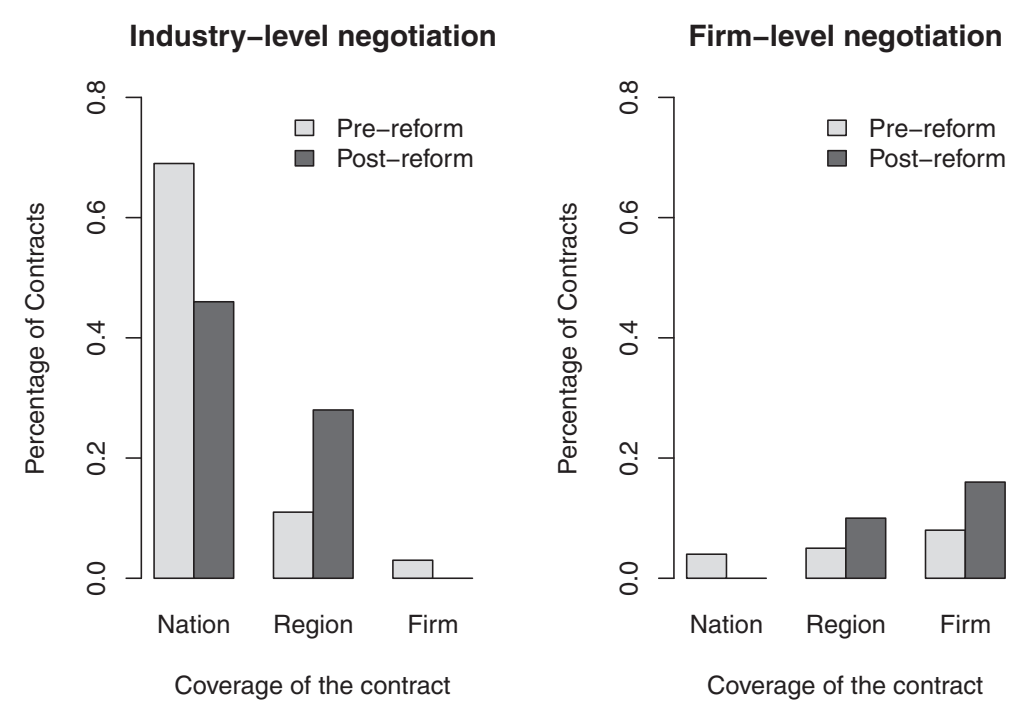

Figure 2 The effect of 1990's reforms on negotiations. Regional coverage refers to an agreement binding within a city, a state or a region. 
Table $\mathbf{2}$ Work rules classification and dummy variable description

\begin{tabular}{|c|c|c|c|}
\hline Work rules & $\begin{array}{l}\text { Before } \\
\text { reforms }\end{array}$ & $\begin{array}{l}\text { After } \\
\text { reforms }\end{array}$ & Dummy variable description: \\
\hline \multicolumn{4}{|l|}{ 1. Working conditions } \\
\hline a. Security & $\begin{array}{l}0.680 \\
(0.469)\end{array}$ & $\begin{array}{c}0.555 \\
(0.502)\end{array}$ & $\begin{array}{l}\text { Does the contract include practices associated with } \\
\text { safety in the workplace? }\end{array}$ \\
\hline b. Equipment & $\begin{array}{l}0.874 \\
(0.333)\end{array}$ & $\begin{array}{c}0.888 \\
(0.317)\end{array}$ & $\begin{array}{l}\text { Is the company committed to provide } \\
\text { job equipment? }\end{array}$ \\
\hline c. Hygiene & $\begin{array}{l}0.213 \\
(0.411)\end{array}$ & $\begin{array}{c}0.185 \\
(0.392)\end{array}$ & $\begin{array}{l}\text { Does the contract include norms associated with } \\
\text { a healthy work environment? }\end{array}$ \\
\hline \multicolumn{4}{|l|}{ 2. Redeployment } \\
\hline a. Promotions & $\begin{array}{l}0.204 \\
(0.404)\end{array}$ & $\begin{array}{l}0.167 \\
(0.376)\end{array}$ & $\begin{array}{l}\text { Does the contract include explicit rules } \\
\text { on promotions within the establishment? }\end{array}$ \\
\hline b. Redeployment & $\begin{array}{l}0.815 \\
(0.390)\end{array}$ & $\begin{array}{l}0.537 \\
(0.503)\end{array}$ & $\begin{array}{l}\text { Does the collective agreement include practices } \\
\text { on redistribution of workers and rehiring? }\end{array}$ \\
\hline c. Leave and absence & $\begin{array}{l}0.689 \\
(0.465)\end{array}$ & $\begin{array}{c}0.592 \\
(0.503)\end{array}$ & $\begin{array}{l}\text { Does the contract include worker's right to get back } \\
\text { to work in case of leaves and absences? }\end{array}$ \\
\hline \multicolumn{4}{|l|}{ 3. Hiring \& Layoffs } \\
\hline a. Staff reduction & $\begin{array}{l}0.349 \\
(0.479)\end{array}$ & $\begin{array}{c}0.148 \\
(0.358)\end{array}$ & $\begin{array}{l}\text { Does the contract includes rules } \\
\text { on discharges and suspensions? }\end{array}$ \\
\hline b. Vacancies & $\begin{array}{c}0.631 \\
(0.485)\end{array}$ & $\begin{array}{c}0.685 \\
(0.468)\end{array}$ & $\begin{array}{l}\text { Does the contract include working rules } \\
\text { on recruitment of workers? }\end{array}$ \\
\hline \multicolumn{4}{|l|}{ 4. Working Week } \\
\hline a. Holidays & $\begin{array}{l}0.427 \\
(0.497)\end{array}$ & $\begin{array}{c}0.462 \\
(0.503)\end{array}$ & $\begin{array}{l}\text { Does the contract explicitly mention } \\
\text { holidays? }\end{array}$ \\
\hline b. Vacations & $\begin{array}{l}0.447 \\
(0.499)\end{array}$ & $\begin{array}{c}0.460 \\
(0.504)\end{array}$ & $\begin{array}{l}\text { Does the contract include practices and indicates } \\
\text { the duration of annual vacations? }\end{array}$ \\
\hline c. Weekly rest & $\begin{array}{l}0.563 \\
(0.498)\end{array}$ & $\begin{array}{c}0.518 \\
(0.504)\end{array}$ & $\begin{array}{l}\text { Does the collective agreement include } \\
\text { rules on weekly rest? }\end{array}$ \\
\hline d. Working week & $\begin{array}{l}0.398 \\
(0.491)\end{array}$ & $\begin{array}{c}0.574 \\
(0.499)\end{array}$ & $\begin{array}{l}\text { Does the contract include rules on the duration of } \\
\text { the working week and hours worked per day? }\end{array}$ \\
\hline \multicolumn{4}{|l|}{ 5. Featherbedding } \\
\hline a. Displacement & $\begin{array}{l}0.184 \\
(0.389)\end{array}$ & $\begin{array}{l}0.093 \\
(0.292)\end{array}$ & $\begin{array}{l}\text { Does the contract include norms on workers displaced } \\
\text { by a technological change or a fall in demand? }\end{array}$ \\
\hline b. Categories & $\begin{array}{l}0.582 \\
(0.495)\end{array}$ & $\begin{array}{c}0.333 \\
(0.476)\end{array}$ & $\begin{array}{l}\text { The contract indicates number and description } \\
\text { of occupational categories }\end{array}$ \\
\hline \multicolumn{4}{|l|}{ 6. Capital Acquisition } \\
\hline a. Technology & $\begin{array}{l}0.184 \\
(0.389)\end{array}$ & $\begin{array}{c}0.185 \\
(0.392)\end{array}$ & $\begin{array}{l}\text { Unions and managers bargain over } \\
\text { incorporation of new technology }\end{array}$ \\
\hline b. Training & $\begin{array}{l}0.339 \\
(0.476)\end{array}$ & $\begin{array}{l}0.259 \\
(0.442)\end{array}$ & $\begin{array}{l}\text { Do contracts include norms to maintain or implement } \\
\text { programs of professional training and development? }\end{array}$ \\
\hline
\end{tabular}

Standard deviations are presented in parentheses.

which sets working conditions for all firms in the industry and covers 23,000 workers, states that both parties need to agree on improving productivity and new methods and technologies. In contrast, the agreement at the firm level between Ford Motor Argentina and the Mechanics Union (SMATA) states that the company can introduce new production methods and technology. The primary focus of this paper is related to the following question: Do featherbedding and capital acquisition work rules bargained after the introduction of policies that promote decentralization increase productivity? 


\subsection{A description of the industry data}

The industry data is obtained from the Argentine Economic Census, which is analogous to the economic census of the U.S. Census Bureau. It was conducted in 1974, 1985 and 1994 by the Argentine National Institute of Statistics and Census (INDEC) and has the advantage of including information on the state where an industry is located. Production data is provided at the four-digit International Standard Industrial Classification (ISIC) level. To define industries consistently over time, it is important to standardize the industry definitions used in the 1974 census (ISIC Rev.2) and 1994 census (ISIC Rev.3). Taking into consideration restrictions imposed by industry definitions and data availability, the production data used in this study includes 55 Argentine manufacturing industries located in 24 provinces.

Our measure of efficiency is constructed as industry net output divided by number of workers. This is due to lack of data on labor and capital to create better measures of productivity. ${ }^{10}$ We present additional details and data sources in the Appendix.

\subsection{Data construction}

The construction of the data set used in this paper involved the following main steps: (1) classification of contracts according to the four-digit ISIC level of aggregation; (2) identification of manufacturing industries and standardization of the industry definitions over time; (3) qualitative analysis of practices included in the contracts and construction of industry-wide work rules.

In step (3), we were able to construct two measures of industry work rules. For each of the 55 manufacturing industries, we created time series of the work rules described in Table 2 in each of the 24 Argentine provinces. If work practices were bargained in firm-level contracts, we aggregated them to the four-digit ISIC level. Our first measure simply indicates whether union contracts in industry $i$ located in state $s$ at time $t$ include a work practice, $W_{i s t}$. Our second measure is defined as,

$$
I_{i s t}=K_{i s t}^{-1} \sum_{k=1}^{K_{i s t}} \xi_{k i s t} \text {, }
$$

where $K_{i s t}$ denotes the number of contracts and $\xi_{k i s t}$ is an indicator variable for whether union contract $k$ includes a work practice.

Using Figure 3, we illustrate the changes of the work rule $W$ after the reforms in each of the manufacturing industries considered in our paper. The figure presents the total number of work rules in union contracts negotiated before and after the policy reform. We see that the new institutional setting generated changes in work practices that were not uniformly extended across manufacturing industries. Thus, we can investigate productivity growth differences between industries by examining variation in work practices over time and across industries. In the next section, we introduce the methods to be applied to a difference-in-difference model of labor productivity. 


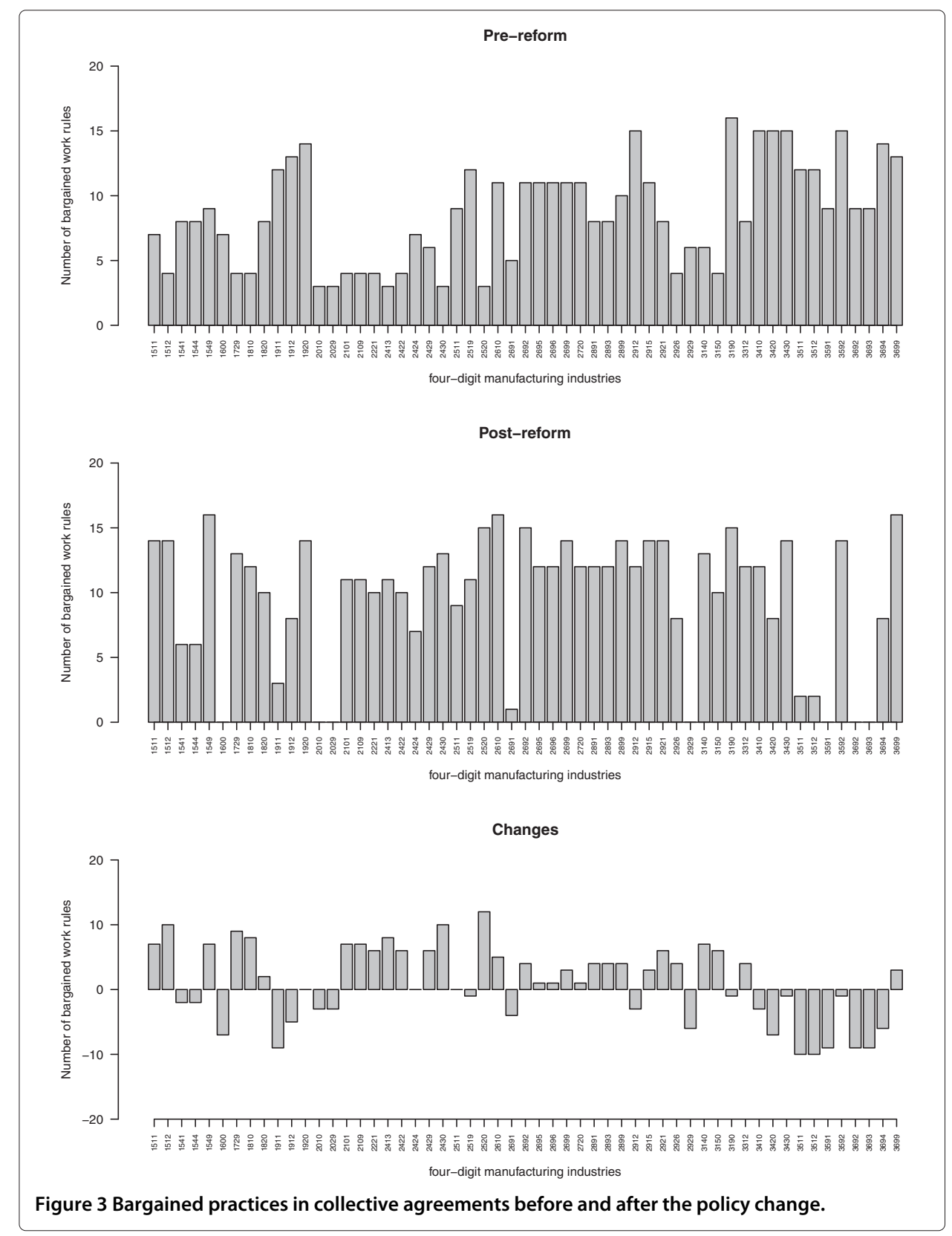

\section{Models and methods}

We begin with a simple productivity equation given by,

$$
y_{i s t}=\delta_{1} W_{i s t}+\delta_{2} A_{t}+\delta_{3} A W_{i s t}+\boldsymbol{x}_{i s t}^{\prime} \boldsymbol{\beta}+\epsilon_{i s t},
$$

where the unit of observation is the productivity of industry $i$ in state $s$ at time $t$. The variable $y_{i s t}$ is defined as the logarithm of the quantity of net output $q_{i s t}$ divided by the number of workers $l_{i s t}$. The variable $y_{i s t}$ may also measure productivity growth. While the variable $W_{i s t}$ indicates whether union contracts affecting industry $i$ include a work practice, the variable $A_{t}$ is an indicator variable for years after the policy reform initiated in 1991. The variable $A W_{i s t}$ is defined as the product of the indicator for a bargained work rule, $W_{i s t}$, and the indicator variable for years after the policy change, $A_{t}$. The model also 
includes a set of independent variables, $\boldsymbol{x}_{i s t}$. These variables are described in detail in the Appendix. Lastly, the variable $\epsilon_{i s t}$ is the error term.

\subsection{Estimation}

The model presented in equation (4.1) can be tentatively estimated using simple regression methods. The coefficient $\delta_{1}$ measures the difference in the conditional expected value of labor productivity between industries whose workers bargain over work rule $W$ and industries whose workers do not bargain over work rule $W$. The coefficient $\delta_{2}$ measures the differences in the expected value of productivity after the policy change. The coefficient $\delta_{3}$ measures the difference between productivity of industries whose workers bargain over $W$ and industries whose workers do not bargain over $W$, after the policy change. The changes in the labor legislation and the presence of less prevalent industrywide work rules after the Argentina's reform in the early 1990's would imply a positive coefficient $\delta_{3}$. However, results from estimating (4.1) may be biased because industry latent heterogeneity is likely to be correlated with $W$.

\subsubsection{Unobserved heterogeneity}

We consider a variation of model (4.1) that includes industry effect $\alpha_{i}$ 's and state effect $\mu_{s}$ 's. The industry effects represent differences in managerial abilities and sector externalities affecting labor productivity that are constant over time and across state. The state effects capture industry-invariant and time-invariant differences in regional productivity. After introducing these effects, the previous model can be rewritten using a more convenient notation,

$$
y_{i s t}=\boldsymbol{d}_{i s t}^{\prime} \boldsymbol{\delta}+\boldsymbol{x}_{i s t}^{\prime} \boldsymbol{\beta}+\alpha_{i}+\mu_{s}+u_{i s t}
$$

where $\boldsymbol{\delta}=\left(\delta_{1}, \delta_{2}, \delta_{3}\right)^{\prime}, \boldsymbol{d}_{i s t}=\left(W_{i s t}, A_{t}, A W_{i s t}\right)^{\prime}$. This model can be easily estimated considering fixed effects methods (see, e.g., Baltagi 2008 and Hsiao 2003). Under the assumption that $\mathbb{E}\left(u_{i s t} \mid \boldsymbol{d}_{i s t}, \boldsymbol{x}_{i s t}, \alpha_{i}, \mu_{s}\right)=0$, the results are expected to be unbiased. Following the recent literature on inconsistent standard errors in panel data, we cluster the standard errors at the province level (e.g., Angrist and Pischke 2009; Cameron et al. 2008, 2010; Stock and Watson 2008).

\subsubsection{Endogenous covariates}

Since in the 1990's unions and firms bargained over work rules and productivity, we estimate equation (4.2) using Two Stage Least Squares (TSLS) methods. The suspected endogenous variables $\left(W_{i s t}, A W_{i s t}\right)$ are instrumented using the average number of employees covered by union contracts and the average length of contracts in other industries and states. These instruments should capture variation associated with the policy reforms that is unrelated to productivity advances in industry $i$ located in state $s$.

\subsection{A quantile regression approach}

A growing body of the literature investigates the distributional effects of policy (see, e.g., Bandiera et al. 2010; Bitler et al. 2006). The studies show that the conditional mean model may provide an incomplete description of the effect of a policy on the outcome of interest. This section introduces two simple approaches designed to overcome the limitations 
of classical methods in the presence of heterogeneous policy effects, while addressing individual heterogeneity and the possibility of endogenous covariates.

A quantile regression version of model (4.2) is,

$$
Q_{i s t}\left(\tau \mid \boldsymbol{d}_{i s t}, \boldsymbol{x}_{i s t}, \alpha_{i}, \mu_{s}\right)=\boldsymbol{d}_{i s t}^{\prime} \boldsymbol{\delta}(\tau)+\boldsymbol{x}_{i s t}^{\prime} \boldsymbol{\beta}(\tau)+\alpha_{i}(\tau)+\mu_{s}(\tau),
$$

where $\tau$ is a quantile in $(0,1)$ and $Q(\cdot \mid \cdot)$ is the $\tau_{j}$-th conditional quantile function. The parameter $\left(\boldsymbol{\delta}(\tau)^{\prime}, \boldsymbol{\beta}(\tau)^{\prime}\right)^{\prime}$ provides an opportunity for investigating how the policy variables and other independent variables influence the location, scale and shape of the conditional distribution of our productivity measure. For instance, if we have an identically, independently distributed error term distributed as $F$ and one covariate $W_{i s t}$, the quantile functions $Q_{Y_{i t}}(\tau \mid \cdot)$ are parallel lines with parameter $\left.\left(\beta_{0}(\tau), \delta_{1}\right)\right)^{\prime}$, and the distance between them is the difference between the intercept terms. It is possible, however, that $\delta_{1}(\tau)$ changes with the quantile $\tau$, suggesting lines with different slopes.

In this paper, we accommodate existing methods to estimate the conditional quantile function (4.3). We first introduce a simple extension to the fixed effects estimator proposed by Koenker (2004), allowing for industry and state location shift effects on the conditional quantiles of labor productivity. Let $C(\cdot)$ be the summation of quantile regression check functions,

$$
C(\tau ; \boldsymbol{\delta}, \boldsymbol{\beta}, \boldsymbol{\alpha}, \boldsymbol{\mu})=\sum_{i=1}^{N} \sum_{s=1}^{S} \sum_{t=1}^{T} \rho_{\tau}\left(y_{i s t}-\boldsymbol{d}_{i s t}^{\prime} \boldsymbol{\delta}-\boldsymbol{x}_{i s t}^{\prime} \boldsymbol{\beta}-\alpha_{i}-\mu_{s}\right),
$$

where $\rho_{\tau}$ is the classical quantile regression check function (see, e.g., Koenker 2005). We follow Koenker's approach of jointly estimating the parameter of interest and the nuisance parameters, because standard panel data transformations are not available in quantile regression. An estimator for a model with industry and state effects is defined as,

$$
\left(\hat{\boldsymbol{\delta}}(\tau)^{\prime}, \hat{\boldsymbol{\beta}}(\tau)^{\prime}, \hat{\boldsymbol{\alpha}}(\tau)^{\prime}, \hat{\boldsymbol{\mu}}(\tau)^{\prime}\right)^{\prime}=\operatorname{argmin}\{C(\boldsymbol{\tau} ; \boldsymbol{\delta}, \boldsymbol{\beta}, \boldsymbol{\alpha}, \boldsymbol{\mu})\} .
$$

To address a potential problem of endogenous covariates, we accommodate the method proposed by Harding and Lamarche (2009). Consider the objective function for the conditional instrumental quantile relationship that is given by:

$$
R(\tau, \boldsymbol{\delta} ; \boldsymbol{\beta}, \boldsymbol{\gamma}, \boldsymbol{\alpha}, \boldsymbol{\mu})=\sum_{i=1}^{N} \sum_{s=1}^{S} \sum_{t=1}^{T} \rho_{\tau}\left(y_{i s t}-\boldsymbol{d}_{i s t}^{\prime} \boldsymbol{\delta}-\boldsymbol{x}_{i s t}^{\prime} \boldsymbol{\beta}-\alpha_{i}-\mu_{s}-\hat{\boldsymbol{w}}_{i s t}^{\prime} \boldsymbol{\gamma}\right),
$$

where the term $\hat{\boldsymbol{w}}_{\text {ist }}$ is the vector of instruments introduced by Chernozhukov and Hansen (2006). In practice, it is possible to construct $\hat{\boldsymbol{w}}$ by a least squares projection of the endogenous variables $\boldsymbol{d}$ on the instruments $\boldsymbol{w}$, exogenous variables $\boldsymbol{x}$ and individual effects. The procedure in Harding and Lamarche (2009) is similar to the one developed by Chernozhukov and Hansen $(2006,2008)$ and proceeds in two steps. First they minimize the objective function above for $\boldsymbol{\beta}, \boldsymbol{\alpha}, \boldsymbol{\mu}$, and $\boldsymbol{\gamma}$ as functions of $\tau$ and $\boldsymbol{\delta}$,

$$
\{\hat{\boldsymbol{\beta}}(\tau, \boldsymbol{\delta}), \hat{\boldsymbol{\alpha}}(\tau, \boldsymbol{\delta}), \hat{\boldsymbol{\mu}}(\tau, \boldsymbol{\delta}), \hat{\boldsymbol{\gamma}}(\tau, \boldsymbol{\delta})\}=\operatorname{argmin}\{R(\tau, \boldsymbol{\delta} ; \boldsymbol{\beta}, \boldsymbol{\gamma}, \boldsymbol{\alpha})\} .
$$

Then they estimate the coefficient on the endogenous variable $\boldsymbol{d}$ by finding the value of $\delta$, which the following quadratic function defined on $\gamma$ :

$$
\hat{\boldsymbol{\delta}}(\tau)=\underset{\delta \in \mathcal{D}}{\operatorname{argmin}}\left\{\hat{\boldsymbol{\gamma}}(\tau, \boldsymbol{\delta})^{\prime} \boldsymbol{A} \hat{\boldsymbol{\gamma}}(\tau, \boldsymbol{\delta})\right\},
$$

for a given positive definite matrix $\boldsymbol{A} .{ }^{11}$ To obtain standard errors and do basic inference, we simply accommodate the covariance matrices obtained in Koenker (2004) and Harding 
and Lamarche (2009). The interested reader can find additional details in Chernozhukov and Hansen (2006, 2008), Koenker (2005), and Lamarche (2010).

\section{Empirical results}

This section presents results on basic regression models that are employed to document the effect of work rules on labor productivity in the Argentine manufacturing industry. Tables 3 and 4 present evidence of the effect of work rules on two measures of productivity. While columns (1) and (2) present results for labor productivity equations, columns

Table 3 Results of the effect of individual work rules on productivity

\begin{tabular}{|c|c|c|c|c|}
\hline \multirow{3}{*}{ Individual working rules } & \multicolumn{4}{|c|}{ Labor productivity specifications } \\
\hline & \multicolumn{2}{|c|}{ Level } & \multicolumn{2}{|c|}{ Growth } \\
\hline & (1) & (2) & (3) & (4) \\
\hline \multirow[t]{2}{*}{ Displacement } & $-0.331^{\dagger}$ & $-0.321^{*}$ & 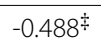 & $-0.475^{\ddagger}$ \\
\hline & $(0.152)$ & $(0.191)$ & $(0.239)$ & $(0.262)$ \\
\hline \multirow[t]{2}{*}{ After reforms } & $2.130^{*}$ & $2.129^{*}$ & $1.052^{\ddagger}$ & $1.048^{*}$ \\
\hline & $(0.350)$ & $(0.197)$ & $(0.515)$ & $(0.269)$ \\
\hline \multirow[t]{2}{*}{ Displacement after reforms } & $0.367^{*}$ & 0.364 & $0.544^{\dagger}$ & $0.546^{\dot{t}}$ \\
\hline & $(0.120)$ & $(0.227)$ & $(0.259)$ & $(0.305)$ \\
\hline F-test (p-value) & - & 0.000 & - & 0.000 \\
\hline Sargan test ( $p$-value) & - & 0.209 & - & 0.330 \\
\hline \multirow[t]{2}{*}{ Categories } & $-0.628^{*}$ & $-0.616^{*}$ & -0.779 & $-0.763^{*}$ \\
\hline & $(0.162)$ & $(0.185)$ & $(0.465)$ & $(0.246)$ \\
\hline \multirow[t]{2}{*}{ After reforms } & $2.053^{*}$ & $2.056^{*}$ & $1.250^{\dagger}$ & $1.250^{*}$ \\
\hline & $(0.404)$ & $(0.209)$ & $(0.573)$ & $(0.285)$ \\
\hline \multirow[t]{2}{*}{ Categories after reforms } & 0.340 & 0.336 & 0.020 & 0.021 \\
\hline & $(0.177)$ & $(0.224)$ & $(0.412)$ & $(0.302)$ \\
\hline F-test (p-value) & - & 0.000 & - & 0.000 \\
\hline Sargan test ( $p$-value) & - & 0.757 & - & 0.870 \\
\hline \multirow[t]{2}{*}{ Technology } & -0.195 & -0.192 & -0.421 & -0.415 \\
\hline & $(0.195)$ & $(0.206)$ & $(0.271)$ & $(0.287)$ \\
\hline \multirow[t]{2}{*}{ After reforms } & $1.863^{*}$ & $1.860^{*}$ & 0.776 & $0.767^{*}$ \\
\hline & $(0.357)$ & $(0.187)$ & $(0.555)$ & $(0.256)$ \\
\hline \multirow[t]{2}{*}{ Technology after reforms } & $0.905^{*}$ & $0.910^{*}$ & $1.183^{\dagger}$ & $1.197 *$ \\
\hline & $(0.243)$ & $(0.254)$ & $(0.438)$ & $(0.351)$ \\
\hline F-test ( $p$-value) & - & 0.000 & - & 0.000 \\
\hline Sargan test ( $p$-value) & - & 0.780 & - & 0.158 \\
\hline \multirow[t]{2}{*}{ Training } & $-0.545^{\dagger}$ & $-0.546 *$ & $-0.867^{*}$ & $-0.869^{*}$ \\
\hline & $(0.223)$ & $(0.211)$ & $(0.278)$ & $(0.291)$ \\
\hline \multirow[t]{2}{*}{ After reforms } & $1.861^{*}$ & $1.857^{*}$ & 0.837 & $0.819^{*}$ \\
\hline & $(0.364)$ & $(0.199)$ & $(0.521)$ & $(0.270)$ \\
\hline \multirow[t]{2}{*}{ Training after reforms } & $0.970^{*}$ & $0.977^{*}$ & $1.196^{*}$ & $1.225^{*}$ \\
\hline & $(0.215)$ & $(0.280)$ & $(0.305)$ & $(0.383)$ \\
\hline F-test (p-value) & - & 0.000 & - & 0.000 \\
\hline Sargan test (p-value) & - & 0.671 & - & 0.910 \\
\hline Basic and additional controls & Yes & Yes & Yes & Yes \\
\hline State effects & Yes & Yes & Yes & Yes \\
\hline Industry effects & Yes & Yes & Yes & Yes \\
\hline Number of observations & 1030 & 1030 & 899 & 899 \\
\hline
\end{tabular}


Table 4 The effect of complementary work rules on productivity

\begin{tabular}{|c|c|c|c|c|}
\hline \multirow{3}{*}{ Complementary practices } & \multicolumn{4}{|c|}{ Labor productivity specifications } \\
\hline & \multicolumn{2}{|c|}{ Levels } & \multicolumn{2}{|c|}{ Growth } \\
\hline & (1) & (2) & (3) & (4) \\
\hline \multirow[t]{2}{*}{ Displacement } & $-0.649 *$ & $-0.649^{*}$ & $-1.088^{*}$ & $-1.089 *$ \\
\hline & $(0.136)$ & $(0.244)$ & $(0.302)$ & $(0.329)$ \\
\hline \multirow[t]{2}{*}{ Categories } & $-0.772^{\dagger}$ & $-0.749^{*}$ & -0.588 & -0.560 \\
\hline & $(0.303)$ & $(0.285)$ & $(0.646)$ & $(0.381)$ \\
\hline \multirow[t]{2}{*}{ Technology } & 0.123 & 0.117 & -0.025 & -0.034 \\
\hline & $(0.211)$ & $(0.286)$ & $(0.353)$ & $(0.391)$ \\
\hline \multirow[t]{2}{*}{ Training } & -0.328 & -0.329 & $-0.667^{\dagger}$ & $-0.666^{\ddagger}$ \\
\hline & $(0.251)$ & $(0.279)$ & $(0.312)$ & $(0.386)$ \\
\hline \multirow[t]{2}{*}{ After reforms } & $1.630^{*}$ & $1.631^{*}$ & 0.676 & $0.670^{\dagger}$ \\
\hline & $(0.398)$ & $(0.239)$ & $(0.556)$ & $(0.327)$ \\
\hline \multirow[t]{2}{*}{ Displacement after reforms } & -0.247 & -0.236 & 0.129 & 0.143 \\
\hline & $(0.276)$ & $(0.275)$ & $(0.381)$ & $(0.371)$ \\
\hline \multirow[t]{2}{*}{ Categories after reforms } & 0.195 & 0.188 & -0.367 & -0.372 \\
\hline & $(0.280)$ & $(0.275)$ & $(0.504)$ & $(0.371)$ \\
\hline \multirow[t]{2}{*}{ Technology after reforms } & $0.831^{\dagger}$ & $0.843^{\ddagger}$ & $1.193^{\dagger}$ & $1.216^{\dagger}$ \\
\hline & $(0.355)$ & $(0.449)$ & $(0.505)$ & $(0.603)$ \\
\hline \multirow[t]{2}{*}{ Training after reforms } & $0.799^{*}$ & $0.786^{\dagger}$ & $1.038^{*}$ & $1.024^{\dagger}$ \\
\hline & $(0.260)$ & $(0.383)$ & $(0.302)$ & $(0.516)$ \\
\hline F-test ( $p$-value) & - & 0.000 & - & 0.000 \\
\hline Sargan test (p-value) & - & 0.695 & - & 0.568 \\
\hline Basic controls & Yes & Yes & Yes & Yes \\
\hline Additional controls & Yes & Yes & Yes & Yes \\
\hline State effects & Yes & Yes & Yes & Yes \\
\hline Industry effects & Yes & Yes & Yes & Yes \\
\hline Number of observations & 1030 & 1030 & 899 & 899 \\
\hline
\end{tabular}

(3) and (4) present results for productivity growth equations. All the variations of the models include, in addition to the variables of interest, industry and state fixed effects, and control variables (see the Appendix for a more detailed description of the variables). ${ }^{12}$

\subsection{Panel data results}

The results presented in column (1) of Table 3 indicate that displacement practices have a significant, negative effect on productivity, suggesting that contracts with practices on displacement of workers might limit manager's ability to do work in the most efficient manner. We find, however, that these practices seem to positively affect productivity in the period after the reforms. The evidence seems to imply that work-wide practices limit management effectiveness to conduct production operations, but practices are effective if they are not imposed by high-level negotiations.

Moreover, the results in column (1) suggest that industries with contracts that include practices on occupational categories and training have lower productivity than industries with contracts that do not include these work rules. The effect of practices on technology acquisition is negative, but insignificant at standard levels. We also find that practices on physical and human capital acquisition lead to productivity advances in the 
period after the reforms. Lastly, the evidence presented in column (3) suggests that practices on physical and human capital bargained after the reforms increase productivity growth. ${ }^{13}$

\subsection{Instrumental variable results}

The period of negotiation characterized by industry-wide work practices imposed a unified view on ways of conceiving and implementing productivity-based methods. In the early 1990's, the collective agreements introduced alternative methods of evaluating and rewarding productivity (Catalano and Novik 1998). If these practices are negotiated at the industry level and are correlated with industry latent innovation or state's productivity, our previous results represent unbiased estimates of the effects of interest. The fixed effects strategies employed in columns (1) and (3) of Table 3 would provide reliable estimates of the policy parameter. However, one may argue that industries' level of innovation did not remain constant in the period after the policy change, and therefore, practices could be negotiated more often in industries with high level of innovation. We employ TSLS methods in models with fixed effects to account for the possibility of an endogenous policy variable.

Ideally, we would like to use as instruments external shocks to the industry that hit the negotiation process but not industry productivity. The reform introduced in the 1990's represents an external shock, but practices are suspected to be endogenous because unions and firms bargain over practices that affect productivity. To instrument work rule $W$ bargained in industry $i$ and state $s$, we use average number of employees covered by union contracts and average length of contracts in other industries located in other states. ${ }^{14}$ The instruments represent features of the weakening of the industry-wide collective bargaining uncorrelated with latent determinants of productivity in industry $i$ in state $s$. It might be possible however that aggregate shocks over time drive productivity and negotiations in other states but the model includes a variable that captures time effects common across industries and states, $A_{t}$. In addition, the models are estimated using clustered standard errors. Thus, the number of employees and contract's duration in other industries that are distant to industry $i$ in state $s$ capture variation associated with the policy reforms that is unrelated to productivity advances in industry $i .{ }^{15}$ Table 3 offers evidence that the instruments pass the standard test of overidentification, and instruments and endogenous variables are strongly correlated (see also the Appendix).

Table 3 presents instrumental variable results of the effect of work practices on productivity and productivity growth. The results presented in column (2) suggest that productivity is higher in industries with contracts that do not include industrywide rules on displacement of workers and categories of workers. We also find that practices on technology and training after the policy change increase productivity. Therefore, the evidence continues to suggest that the policies that weakened the traditional industry-wide collective agreements increased productivity in the manufacturing sector. The results for the productivity growth equations estimated in column (4) also indicate a significant effect of the policy. Physical and human capital practices increase mean productivity by $1.20 \%$ and $1.22 \%$ in the period after the reforms. 


\subsection{Complementary practices}

The existing empirical literature examines the effect of individual work practices on productivity as well as the effect of clusters of complementary practices on productivity (see, e.g., Bartel 1995 and Ichniowski et al. 1997). Complementary work rules may be advantageous because one work rule may be more effective if it is adopted with other practices that stimulate worker's productivity. Therefore, there may exist productivity gains arising from adopting one practice along with other work practices. The theoretical literature seems to also support the notion that policies should be analyzed within a coherent incentive system (Holmstrom and Milgrom 1994, Milgrom and Roberts 1990).

To model the possibility of cluster of complementary practices, we estimate a model that incorporates the practices analyzed in Table 3. Using Table 4, we show results from estimating simultaneously the effect of featherbedding and capital acquisition practices on our measures of productivity. We find that while industry-wide practices on displacement of workers and categories have an adverse effect on productivity, technology and training bargained after the reforms seem to increase productivity. Moreover, the results shown in column (4) continue to suggest that practices on technology and training introduced after the government weakened industry-wide agreements have a positive, significant effect on productivity growth.

\subsection{The distributional effect of the policy reform}

The reforms would similarly impact low- and high- productivity industries if industry-wide bargaining would have equally restricted firms level of efficiency across industries. However, the reforms could affect industries differently, because the productivity impact of a marginal firm that becomes able to adopt an innovation under the decentralized framework is larger in a high-productivity industry than in a lowproductivity industry. In this section, we focus on the heterogeneous effects of the policy reform across the conditional distribution of productivity advances by estimating quantile regression models with fixed effects. We use instrumental variables to estimate a productivity growth equation similar to the one presented in Table 3. In addition to the effect of the policy, we include indicators for type of contracts, type of workers covered by the contract, geographical coverage of the contract, state's population, real gross geographical product per capita and the shares of employment in the main sectors. Moreover, the models include industry and state effects.

Figure 4 presents estimates of the effect of union practices on labor productivity growth as a function of the quantile $\tau$ of the conditional distribution. To improve the presentation of the results, we do not report estimates on the coefficient on $A_{t}, \delta_{2}(\tau)$, which turn to be positive and significant across the quantiles of the conditional distribution. The panels present results on the effect of capital acquisition rules on productivity. In each graph, the continuous line denotes estimates of the effect of a work rule and the dashed line with dots denotes estimates of the effect of a work rule after the reforms.

The advantage of examining the distributional effect of the decentralization policies can be seen in the left panel of Figure 4. While the evidence on technology indicates no significant effect at the mean level (Table 3, column (4)), we see that the effect of 

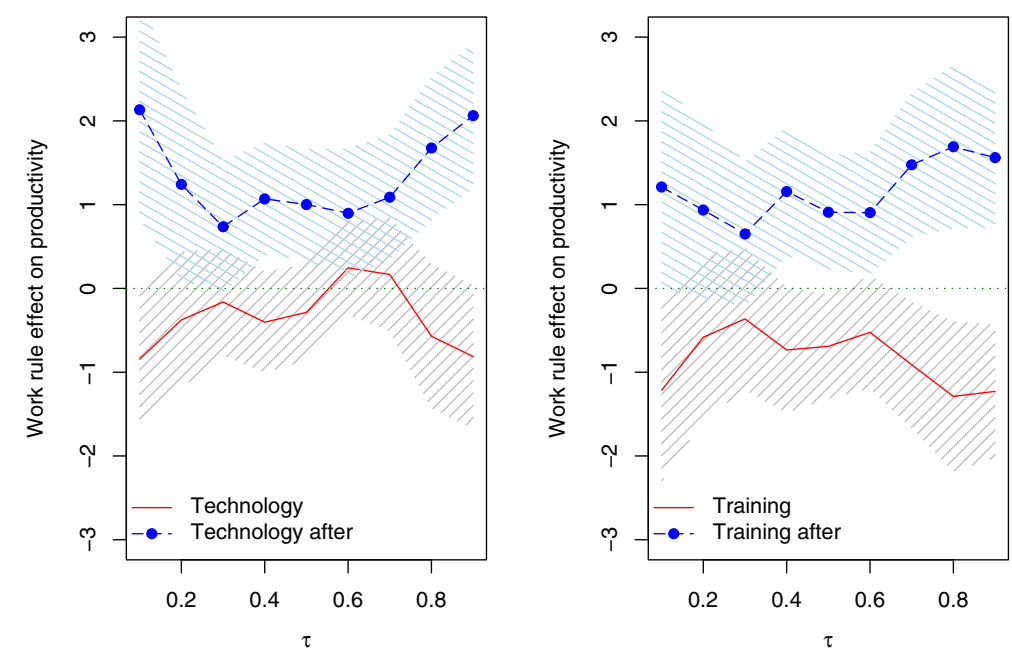

Figure 4 The distributional effect of union practices on productivity growth. The quantiles of the conditional distribution are indicated by $\tau$. The shaded areas denote 90 percent (pointwise) confidence intervals.

technology is associated with a weak, yet significant, productivity loss at the 0.1 quantile. Moreover, we find that technology and training after the reforms have a significant and positive effect at the upper tail of the conditional response distribution. These practices do not seem to limit management effectiveness to conduct production operations in highproductivity industries after the reforms were implemented.

\subsection{Quantifying heterogeneous effects}

The previous empirical evidence invites the following question: How harmful are industry-wide practices on technology acquisition on labor productivity growth? In order to answer this question, we estimate a variation of equation (4.2) and perform a series of in-sample simulations. We replace the indicator variable $W$ with a variable $I$ defined as in equation (3.1). By replacing $W$ by $I$ in equation (4.2), we obtain the following equation:

$$
y_{i s t}=\delta_{1} I_{i s t}+\delta_{2} A_{t}+\delta_{3}\left(I_{i s t} \times A_{t}\right)+\boldsymbol{x}_{i s t}^{\prime} \boldsymbol{\beta}+\alpha_{i}+\mu_{s}+u_{i s t} .
$$

To address the concern of endogenous regressors and the possibility of heterogeneous effects, we employ the quantile regression instrumental variable approach introduced in Section 4.

Industry-wide work rules set working conditions for all potentially heterogeneous firms in an industry, and therefore, the variable $I_{i s t} \rightarrow 1$ may be interpreted as implying higher barriers affecting firms' efficiency and ability to organize production. Because $I_{i s t}$ can be seen as a continuous variable, we can estimate a counterfactual scenario. We let the variable $I$ be equal to $10 \%$ and then we recompute the model prediction for $I$ equal to $11 \%$. The difference between the model prediction which includes $I=0.10$ and the model prediction which includes $I=0.11$ corresponds to our estimate of the effect of technology acquisition practices on labor productivity growth. 


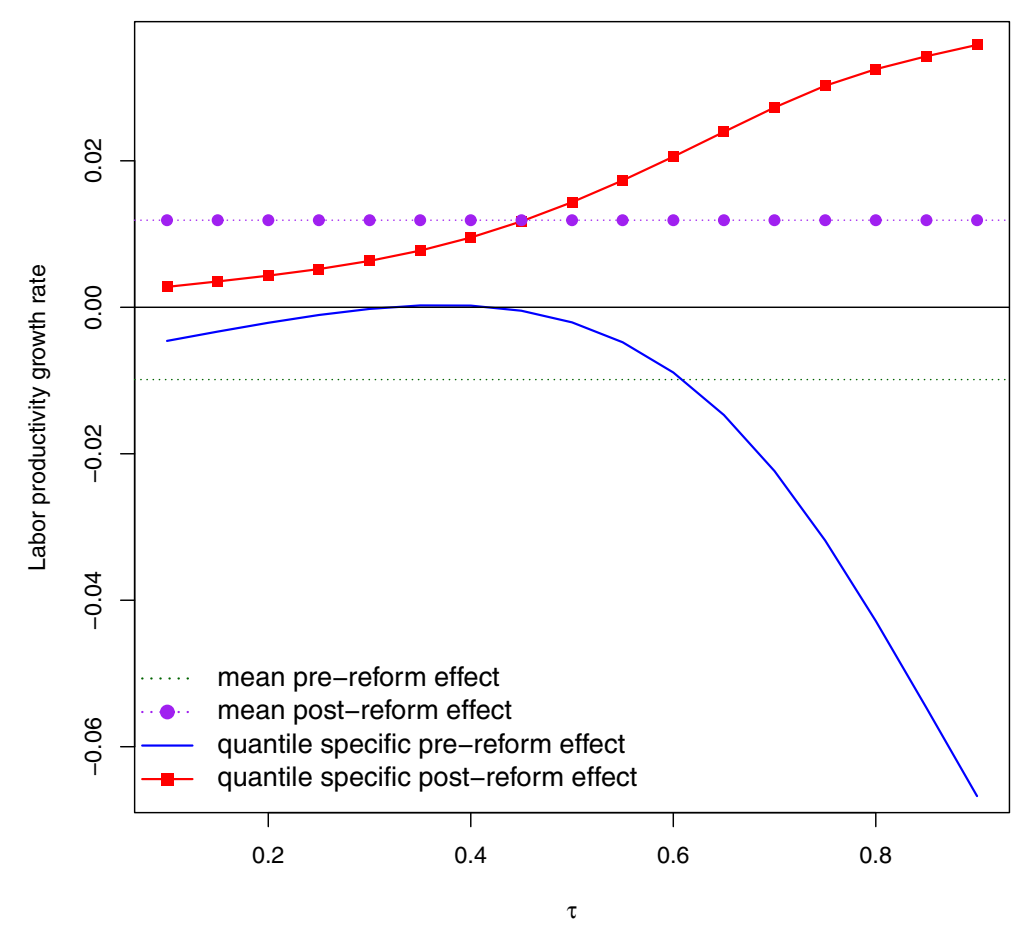

Figure 5 Quantifying the heterogeneous effect of practices on the incorporation of new technology on labor productivity growth. The quantiles of the conditional distribution are indicated by $\tau$.

We present the results in Figure 5. The figure restricts attention to the impact of technology acquisition practices on productivity growth in 55 manufacturing industries. The mean productivity growth change is $-0.9 \%$ in the period pre-reform, increasing to $1.0 \%$ in the period post-reform. These estimates, however, miss important information. Union practices on technology seem to have a modest negative effect of less than $1 \%$ among low-productivity growth industries, but they reduce labor productivity among highproductivity growth industries by $6.7 \%$. The results for the period post-reform suggest that productivity growth improves between $0.2 \%$ and $3.6 \%$ under weakened industry-wide practices on the incorporation of new technology.

We extend the series of simulation exercises to the analysis of work rules on training. Figure 6 investigates how harmful are industry-wide practices on training on productivity growth. As in the case of practices on technology, we find that training seems to have a negligible effect among low productivity growth industries. Union practices on training in an economy promoting policies to weaken industry-wide agreements appears to

Table 5 Tests for the significance and equality of productivity growth rates

\begin{tabular}{lcccccc}
\hline Effects of interest & \multicolumn{3}{c}{ Quantiles } & \multicolumn{3}{c}{ Pair of quantiles } \\
& $\mathbf{0 . 1}$ & $\mathbf{0 . 5}$ & $\mathbf{0 . 9}$ & $\mathbf{0 . 1 - 0 . 5}$ & $\mathbf{0 . 1 - 0 . 9}$ & $\mathbf{0 . 5 - 0 . 9}$ \\
\hline Technology pre-reform & 0.983 & 0.774 & 0.000 & 0.991 & 0.888 & 0.000 \\
Technology post-reform & 0.623 & 0.002 & 0.000 & 0.779 & 0.283 & 0.026 \\
Training pre-reform & 0.995 & 0.987 & 0.998 & 0.996 & 0.999 & 1.000 \\
Training post-reform & 0.273 & 0.300 & 0.004 & 0.464 & 0.129 & 0.142 \\
\hline P-values are reported & & & & &
\end{tabular}


be beneficial for high productivity growth industries, although practices on technology acquisition have a larger impact than practices on training.

Lastly, we test if the productivity changes reported in Figures 5 and 6 are significantly different. We test two hypotheses. ${ }^{16}$ We first check whether productivity growth rates are significantly different from zero at $\tau=\{0.1,0.5,0.9\}$. Second, we test the equality of gains across quantiles $\tau$, considering pairs $\left(\tau_{i}, \tau_{j}\right)$ for $i \neq j$. For instance, the fifth column in Table 5 shows the p-value of a Wald-type test for the hypothesis that the productivity growth rate at the 0.1 quantile is equal to the productivity growth rate at the 0.5 quantile. We find that (a) productivity growth induced by changes in technology and training in the period after the reforms are statistically significantly different than zero at the 0.9 quantile, and (b) we reject the equality of gains induced by changes in technology at the 0.5 and 0.9 quantiles. While these work practices do appear to increase economic efficiency in the post-reform period, technology acquisition seems to have a significant adverse effect on high-productivity growth industries under industry-wide contracts.

\section{Discussion and final remarks}

This paper documents the effect of industry-wide practices on productivity. Argentina's policies to promote decentralization of the negotiation between firms and unions invite an opportunity to answer questions for developing countries. We first examine the hypothesis that unions add costs that limit firm's organization and flexibility to incorporate physical capital. We find that industry-wide practices on displacement of workers,

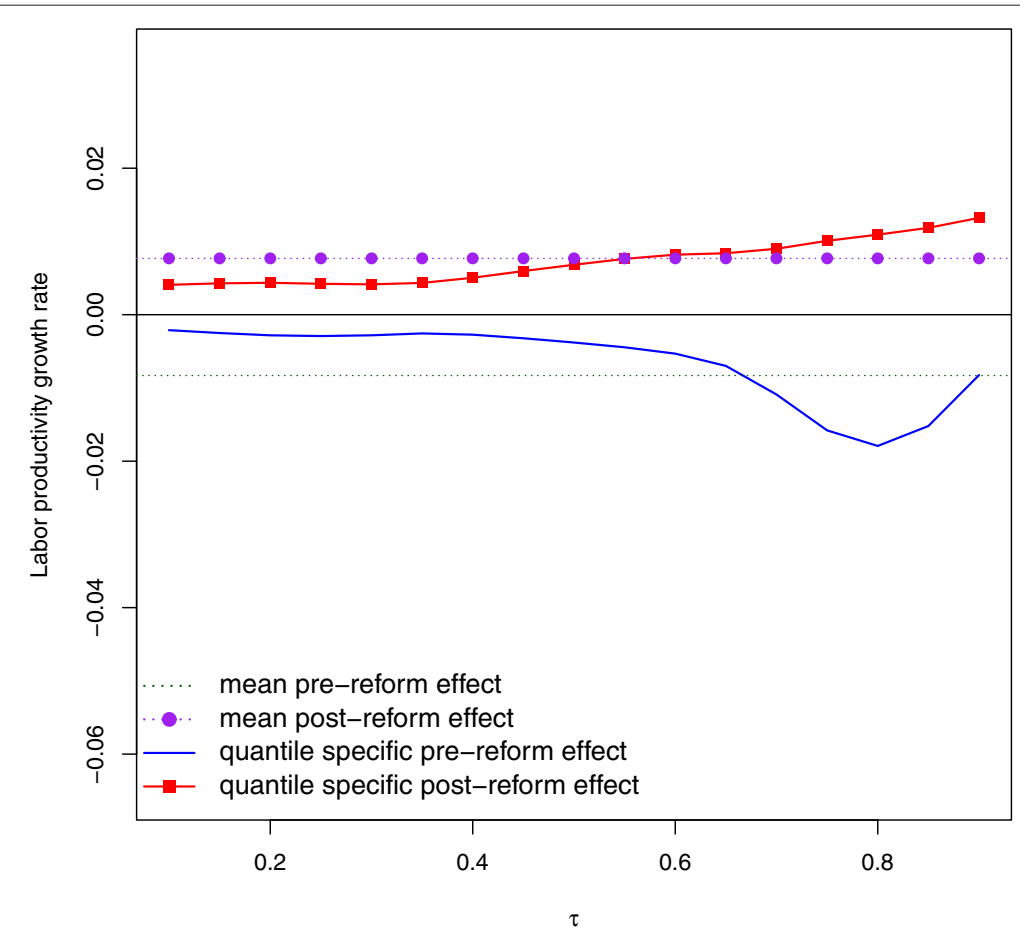

Figure 6 Quantifying the heterogeneous effect of practices on training on labor productivity growth. The quantiles of the conditional distribution are indicated by $\tau$. 
technology acquisition and training have a negative impact on productivity. Union practices on technology acquisition are heterogeneous, having a modest negative effect on low-productivity growth industries and a significant adverse effect on high-productivity growth industries. In the post-reform period however, productivity improves and work practices do not appear to restrict economic efficiency.

The current analysis focuses on whether a practice was included in a contract, and remains silent on the mechanisms through which union practices affect both productivity and within-industry productivity. This is due to the lack of suitable data. Further research is also needed on other costs unions in developing countries may impose on firm's management. These factors are associated with disruptions in the production process from strikes and pressures to increase wages and benefits. Nevertheless, we hope that the evidence presented in this article will stimulate further research on the subject.

\section{Endnotes}

${ }^{1}$ See also classical papers by Allen (1987), Brown and Medoff (1978), Clark (1984), and Groves et al. (1994). More recently, Dunne et al. (2010) investigate competition and productivity in the US cement industry. Addison and Hirsch (1989) and Dowrick and Spencer (1994) report evidence that relates unions with lower total factor productivity growth in the US, where there is decentralized collective bargaining.

${ }^{2}$ Bester and Petrakis (1993) consider a similar assumption to the one adopted in this paper. An alternative condition is to assume that all firms have the opportunity of implementing an innovation. However, it has been shown that results are qualitatively robust to changing this assumption (Haucap and Wey 2004, footnote 9).

${ }^{3}$ It is known that specific investments (e.g., training costs specific to the employer) generate rents, and therefore, after the investment is made, unions may be able to obtain higher benefits as a result of the firm's investment (e.g., Grout 1984, Haucap and Wey (2002, 2004, Ulph and Ulph (1994, 2001)); for a survey, see Malcomson 1997).

${ }^{4}$ The results are stated in Lemma 1 and Proposition 1 in a supplementary Appendix not for publication, which is available from the author upon request.

${ }^{5}$ In the period 1973-1976, industry-wide bargaining was widespread including roughly 7 out of 10 contracts (Bronstein 1978). The negotiations were suspended in 1976, but union contracts remained in force until they were renegotiated in 1988 and 1989.

${ }^{6}$ Argentina implemented a liberalization program, privatized public enterprises, and deregulated the economy. The labor reform included the introduction of contracts for temporary workers and a decentralization framework for collective bargaining. The decree 2284 in 1991 deregulated collective labor agreements. The interested reader can find additional details on labor market regulations and reform bills in Etchemendy (2001) and Murillo (1997).

${ }^{7}$ Following standard practice, contracts were partitioned into subgroups in order to increase the accuracy of the estimates. First, we stratified the population of union contracts in $H$ different stratas. Second, we determined the number of contracts, $n_{h}$, to be selected from each stratum $h$. Lastly, we obtained the samples. After we generated random numbers for the contracts, we ordered them, and we selected the first $n_{h}$ contracts. Additional details are available upon request.

${ }^{8}$ We do not include other industries in the analysis for two important reasons: (i) industry data from the Argentine Census are available for the manufacturing sector and are not available for other industries in the period 1974-1994 (with the exception of Trade and Services); (ii) several public enterprises in the Electricity, Gas and Water sector and Service sector were privatized in the 1990's, and therefore, they were affected by a policy not analyzed in this study. 
${ }^{9}$ Quebracho is a hard wood produced in the "Gran Chaco" region in northern Argentina and Paraguay.

${ }^{10}$ Our definition is similar to the one used in Stiroh (2002). A number of studies have focused on alternative measures of economic efficiency. For instance, Hsieh and Klenow (2009) consider total factor productivity and estimate differences in marginal products of labor and capital.

${ }^{11}$ It is convenient to consider the asymptotic covariance matrix of $\hat{\gamma}$ (Chernozhukov and Hansen 2006). The requirement is that $\boldsymbol{A}$ be any uniformly positive definite matrix, and for practical convenience, can be $\boldsymbol{A}=\boldsymbol{I}$ or $\hat{\boldsymbol{A}}=(N S T)^{-1} \sum_{i} \sum_{s} \sum_{t} \hat{\boldsymbol{w}}_{i s t} \hat{\boldsymbol{w}}_{i s t}^{\prime}$.

${ }^{12}$ Note that the models do not include time effects. This is to avoid issues of linear dependence with the variable of interest 'After the reforms', $A_{t}$. When we carefully handle non-singularities in the design matrix, we obtain similar results for the coefficients $\delta_{1}$ and $\delta_{3}$ to the ones presented in Table 3. These results are available upon request.

${ }^{13}$ The Appendix presents robustness checks.

${ }^{14}$ It is known that contract's duration is an important component in the collective bargaining process (see, e.g., Dye 1985 and Murphy 1992). The literature documents several factors affecting contract's duration, including cost-of-living adjustments and industry-specific transaction costs. In Argentina, however, the duration of union contracts were dramatically affected by the "ultra-activity" law, which allows contracts to be extended if unions and firms do not agree to a revision. In the period 1975-1998, approximately 90 percent of the contracts were of "indefinite" duration.

${ }^{15}$ The theoretical justification of using contract's duration to instrument the endogenous policy variable also relies on the fact that contracts were extended despite that unions and firms did not agree to a revision. This can be interpreted as implying that productivity in an industry might not be associated with contracts' duration. It may, however, influence productivity in the first year, when firms and unions were less uncertain about contract's duration. We address this concern by using the length of contracts in other industries located in other states.

${ }^{16}$ We implemented a Wald-type test following closely the ideas discussed in Koenker (2005, \$3.3), further elaborated in Lamarche (2008).

\section{Appendix: data set description and sources}

\section{Data sources}

The source of contract data is Argentine Law, Collective Bargaining. Some contracts are available at the site of the Ministerio de Trabajo de la Nación Argentina http://www. trabajo.gov.ar/. The main source of output and labor data is the Economic National Census (CNE) conducted by the Argentine National Institute of Statistics and Census (INDEC). The CNE was conducted in 1974, 1985, and 1994. The source for data on employment is EPH, which is also conducted by INDEC. This survey, which is similar to the CPS in the US, is a large national survey comprised of interviews of 30.000 households in each wave. The source of gross geographical product is SAREP, Secretaría de Asistencia para la Reforma Provincial. The source of per capita GDP (millions of pesos at 1993 prices) in Figure 1 is Ieral, Ministry of Finance and ECLAC (Argentina). The source of data on population is INDEC (Censo Nacional de Población 1980 y 1991).

A few tables and figures contain information obtained from other sources. The total number of contracts and beneficiaries in Table 1 is from Aldao-Zapiola et al. 1994. Lastly, the productivity index presented in Figure 1 is from Asociación de Fábricas the Automotores (ADEFA) and Catalano and Novick's (1998) Tables 2.4 and 2.5. ADEFA 
reports annual production, employment and productivity per worker in the Argentine automobile industry.

\section{Description of the variables}

The collective agreements are classified according to the four digit level of the United Nations International Standard Industrial Classification (ISIC, Rev.3). The group of variables labeled basic controls in the regressions include other contract characteristics: (a) type of contract (indicators for firm-level contract, industry-level contract, or nationallevel contract); (b) type of worker covered by the contract (e.g., indicators for blue collar workers, white collar workers, etc.); (c) geographical coverage of the contract (indicators for whether the contract is binding within a firm, a state, a region, or the nation). The vector of additional controls includes the state-variant variables considered in Galiani et al. (2005). These variables are logarithm of population, the real gross geographical product per capita, and a measure of the state's industry composition. The industry mix is defined

Table 6 Additional empirical evidence on the effect of individual work rules on productivity

\begin{tabular}{|c|c|c|c|c|c|c|}
\hline \multirow{3}{*}{ Individual working rules } & \multicolumn{6}{|c|}{ Labor productivity specifications } \\
\hline & \multicolumn{3}{|c|}{ Level } & \multicolumn{3}{|c|}{ Growth } \\
\hline & (1) & $(2)$ & (3) & (4) & (5) & (6) \\
\hline \multirow[t]{2}{*}{ Displacement } & $-0.262^{*}$ & $-0.359^{\dagger}$ & $-0.224^{\ddagger}$ & -0.198 & $-0.323^{\dagger}$ & -0.276 \\
\hline & $(0.092)$ & $(0.168)$ & $(0.114)$ & $(0.137)$ & $(0.142)$ & $(0.263)$ \\
\hline \multirow[t]{2}{*}{ After reforms } & $2.962^{*}$ & $2.031^{*}$ & $3.140^{*}$ & $1.841^{*}$ & 0.970 & $1.911^{*}$ \\
\hline & $(0.179)$ & $(0.374)$ & $(0.155)$ & $(0.301)$ & $(0.494)$ & $(0.307)$ \\
\hline \multirow[t]{2}{*}{ Displacement after reforms } & $0.641^{*}$ & $0.709^{*}$ & 0.175 & 0.200 & $0.348^{\ddagger}$ & 0.302 \\
\hline & $(0.118)$ & $(0.200)$ & $(0.146)$ & $(0.210)$ & $(0.171)$ & $(0.309)$ \\
\hline \multirow[t]{2}{*}{ Categories } & -0.065 & $-0.350^{*}$ & $-0.415^{*}$ & -0.289 & $-0.385^{\dagger}$ & -0.572 \\
\hline & $(0.085)$ & $(0.111)$ & $(0.109)$ & $(0.211)$ & $(0.181)$ & $(0.423)$ \\
\hline \multirow[t]{2}{*}{ After reforms } & $2.973^{*}$ & $1.956^{*}$ & $3.023^{*}$ & $1.868^{*}$ & $1.062^{\dagger}$ & $1.987^{*}$ \\
\hline & $(0.158)$ & $(0.353)$ & $(0.118)$ & $(0.314)$ & $(0.475)$ & $(0.369)$ \\
\hline \multirow[t]{2}{*}{ Categories after reforms } & $0.509^{*}$ & $0.686^{*}$ & $0.260^{\dagger}$ & 0.074 & 0.039 & 0.041 \\
\hline & $(0.094)$ & $(0.161)$ & $(0.122)$ & $(0.201)$ & $(0.226)$ & $(0.345)$ \\
\hline \multirow[t]{2}{*}{ Technology } & $0.233^{\dagger}$ & -0.001 & -0.062 & -0.267 & -0.318 & -0.357 \\
\hline & $(0.105)$ & $(0.153)$ & $(0.171)$ & $(0.193)$ & $(0.216)$ & $(0.233)$ \\
\hline \multirow[t]{2}{*}{ After reforms } & $3.024^{*}$ & $2.110^{*}$ & $2.849^{*}$ & $1.624^{*}$ & 0.783 & $1.600^{*}$ \\
\hline & $(0.187)$ & $(0.357)$ & $(0.178)$ & $(0.320)$ & $(0.512)$ & $(0.359)$ \\
\hline \multirow[t]{2}{*}{ Technology after reforms } & $0.412^{*}$ & $0.510^{\dagger}$ & $0.745^{*}$ & $0.725^{*}$ & $0.751^{\dagger}$ & $1.046^{\dagger}$ \\
\hline & $(0.130)$ & $(0.180)$ & $(0.209)$ & $(0.246)$ & $(0.266)$ & $(0.417)$ \\
\hline \multirow[t]{2}{*}{ Training } & -0.189 & -0.255 & $-0.571 *$ & -0.198 & -0.247 & $-0.789 *$ \\
\hline & $(0.111)$ & $(0.163)$ & $(0.155)$ & $(0.156)$ & $(0.151)$ & $(0.246)$ \\
\hline \multirow[t]{2}{*}{ After reforms } & $3.108^{*}$ & $2.227^{*}$ & $2.803^{*}$ & $1.777^{*}$ & $0.958^{\ddagger}$ & $1.594^{*}$ \\
\hline & $(0.165)$ & $(0.340)$ & $(0.145)$ & $(0.246)$ & $(0.507)$ & $(0.211)$ \\
\hline \multirow[t]{2}{*}{ Training after reforms } & $0.393^{*}$ & $0.397^{*}$ & $0.965^{*}$ & $0.357^{\dagger}$ & 0.397 & $1.153^{*}$ \\
\hline & $(0.110)$ & $(0.131)$ & $(0.180)$ & $(0.158)$ & $(0.213)$ & $(0.317)$ \\
\hline Basic controls & Yes & Yes & Yes & Yes & Yes & Yes \\
\hline Additional controls & No & Yes & No & No & Yes & No \\
\hline State effects & Yes & Yes & Yes & Yes & Yes & Yes \\
\hline Industry effects & No & No & Yes & No & No & Yes \\
\hline Number of observations & 1945 & 1030 & 1945 & 1090 & 899 & 1090 \\
\hline
\end{tabular}

The symbols $\$, \dagger, *$ denote statistically different from zero at the $0.10,0.05$, and 0.01 level of significance. Clustered standard errors are in parentheses. 
as the share of employment in the main aggregate sectors: manufacturing, trade, services, construction, and other sectors.

\section{Additional empirical evidence}

We now present robustness checks. In all the variants of the model, we find that the effect of technology after the reform is positive and significant, suggesting that decentralized negotiation on technology acquisition lead to productivity gains. The table also illustrates the importance of controlling for observed heterogeneity. Column (1) in Table 6 shows that industry-wide practices on technology acquisition tend to increase productivity. As expected, however, these results are not robust to the inclusion of additional controls for regional disparities. Finally, Table 7 presents evidence that instruments and endogenous variables are strongly correlated.

Table 7 First-stage regression results of the effect of individual work rules on productivity

\begin{tabular}{|c|c|c|c|c|c|}
\hline \multirow{3}{*}{$\begin{array}{l}\text { Endogenous } \\
\text { working rule }\end{array}$} & \multirow[t]{3}{*}{ IV } & \multicolumn{4}{|c|}{ Labor productivity specifications } \\
\hline & & \multicolumn{2}{|c|}{ Level } & \multicolumn{2}{|c|}{ Growth } \\
\hline & & Coefficient & Std error & Coefficient & Std error \\
\hline \multirow[t]{3}{*}{ Displacement } & I & $0.119 *$ & 0.012 & $0.119^{*}$ & 0.012 \\
\hline & $\|$ & $0.041^{*}$ & 0.013 & $0.041^{*}$ & 0.012 \\
\hline & III & 0.003 & 0.008 & 0.003 & 0.008 \\
\hline \multirow[t]{3}{*}{ Displacement After } & I & -0.001 & 0.011 & -0.002 & 0.011 \\
\hline & $\|$ & $0.168^{*}$ & 0.011 & $0.167^{*}$ & 0.011 \\
\hline & III & 0.001 & 0.007 & 0.001 & 0.007 \\
\hline \multirow[t]{3}{*}{ Categories } & I & $0.105^{*}$ & 0.010 & $0.106^{*}$ & 0.009 \\
\hline & $\|$ & $0.026^{\dagger}$ & 0.011 & $0.027^{*}$ & 0.010 \\
\hline & III & $0.013^{\ddagger}$ & 0.007 & $0.012^{\dagger}$ & 0.006 \\
\hline \multirow[t]{3}{*}{ Categories After } & । & -0.012 & 0.009 & -0.011 & 0.009 \\
\hline & $\|$ & $0.157^{*}$ & 0.010 & $0.157^{*}$ & 0.009 \\
\hline & III & 0.008 & 0.006 & 0.008 & 0.006 \\
\hline \multirow[t]{3}{*}{ Technology } & I & $0.119 *$ & 0.011 & $0.120^{*}$ & 0.010 \\
\hline & $\|$ & $0.042^{*}$ & 0.012 & $0.043^{*}$ & 0.011 \\
\hline & III & 0.003 & 0.007 & 0.002 & 0.007 \\
\hline \multirow[t]{3}{*}{ Technology After } & I & -0.003 & 0.011 & -0.002 & 0.010 \\
\hline & $\|$ & $0.167^{*}$ & 0.012 & $0.167^{*}$ & 0.011 \\
\hline & III & 0.002 & 0.007 & 0.002 & 0.007 \\
\hline \multirow[t]{3}{*}{ Training } & I & $0.111^{*}$ & 0.018 & $0.112^{*}$ & 0.018 \\
\hline & $\|$ & $0.032^{\ddagger}$ & 0.019 & $0.033^{\ddagger}$ & 0.019 \\
\hline & III & 0.008 & 0.012 & 0.007 & 0.012 \\
\hline \multirow[t]{3}{*}{ Training After } & I & -0.012 & 0.018 & -0.011 & 0.018 \\
\hline & $\|$ & $0.156^{*}$ & 0.019 & $0.157^{*}$ & 0.019 \\
\hline & III & 0.008 & 0.012 & 0.007 & 0.012 \\
\hline Controls & & Yes & Yes & Yes & Yes \\
\hline State effects & & Yes & Yes & Yes & Yes \\
\hline Industry effects & & Yes & Yes & Yes & Yes \\
\hline Observations & & 1030 & 1030 & 899 & 899 \\
\hline
\end{tabular}

The endogenous variables are instrumented by average number of employees covered by union contracts in other industries and states (I), the average number of employees covered by union contracts in other industries and states in the period after the reforms were introduced (II), and average length of contracts in other industries and states (III). Controls include the variables in Table 3 and an indicator for the period after the reforms were introduced. The symbols $\$, \dagger, *$ denote statistically different from zero at the $0.10,0.05$, and 0.01 level of significance. 


\section{Competing interests}

The IZA Journal of Labor \& Development is committed to the IZA Guiding Principles of Research Integrity. The author declares that he has observed these principles.

\section{Acknowledgements}

I would like to thank Irene Brambilla, George Deltas, Pedro Cavalcanti Ferreira, Sebastian Galiani, Roger Koenker, Catherine Tyler Mooney, Stephen Parente, Guido Porto and seminar participants at the University of La Plata (Argentina) and the 8th IZA/World Bank Conference on Employment and Development. I am grateful to the Editor and a referee for their comments which have improved the paper considerably.

Responsible editor: David Lam

Received: 5 August 2013 Accepted: 23 October 2013

Published: 25 Nov 2013

\section{References}

Addison J, Hirsch B (1989) Union effects on productivity, profits, and growth: has the long run arrived? J Labor Econ 7 : 72-105

Aldao-Zapiola CM, Hülsberg HA, Jaureguiberry CE (1994) Productividad y Negociacion Colectiva. Ediciones Macchi Allen S (1987) Can union labor ever cost less?. Q J Econ 102: 347-73

Angrist JD, Pischke J-S (2009) Mostly harmless econometrics. Princeton University Press, New Jersey

Baltagi B (2008) Econometric analysis of panel data, 4th edn. Wiley, New York

Bandiera O, Larcinese V, Rasul I (2010) Heterogeneous class size effects: new evidence from a panel of university students. Econ J 120(549): 1365-1398

Bartel A (1995) Training, wage growth, and job performance: evidence from a company database. J Labor Econ 13(3): 401-425

Bental B, Demougin D (2006) Incentive contracts and total factor productivity. Int Econ Rev 47: 1033-1055

Bester H, Petrakis E (1993) The incentives for cost reduction in a differentiated industry. Int J Ind Organization 11:519-534

Bitler M, Gelbach J, Hoynes H (2006) What means impact miss: distributional effects of welfare reform experiments. Am Econ Rev 96(4): 988-1012

Bremmels B (1987) How unions affect productivity in manufacturing plants? Ind Labor Relat Rev 40: 241-252

Bronstein A S (1978) Collective bargaining in latin america: problems and trends. Int Labour Rev 117(5): 583-596

Brown C, Medoff J (1978) Trade unions in the production process. J Pol Econ 86: 355-378

Cameron AC, Gelbach J, Miller D (2008) Bootstrap-based improvements for inference with clustered errors. Rev Econ Stat 90: 414-427

Cameron AC, Gelbach JB, Miller DL (2010) Robust inference with multi-way clustering. J Business Econ Stat 29(2): 238-249

Cardoso A, Gindin J (2009) Industrial relations and collective bargaining: Argentina, Brazil and Mexico compared. Working Paper No 5, International Labour Office

Catalano AM, Novick MS (1998) The Argentine automobile industry: redefining production, strategies, markets, and labor relations. In: Tuman JP, Morris JT (eds) Transforming the Latin American automobile industry: unions, workers, and the politics of restructuring. M. E. Sharpe, New York

Chernozhukov V, Hansen C (2006) Instrumental quantile regression inference for structural and treatment effect models. J Econometrics 132(2): 491-525

Chernozhukov V, Hansen C (2008) Instrumental variable quantile regression: a robust inference approach. J Econometrics 142(1): 379-398

Clark K (1984) Unionization and firm performance: the impact on profits, growth, and productivity. Am Econ Rev 95 893-919

Cole HL, Ohanian LE, Riascos A, Schmitz Jr JA (2005) Latin America in the rearview mirror. J Monetary Econ 52(1): 69-107

Dowrick S, Spencer B (1994) Union attitudes to labor-saving innovation: when are unions luddites. J Labor Econ 12 316-344

Dunne T, Klimek SD, Schmitz JA (2010) Competition and productivity: evidence from the post WWII U.S. cement industry. US Census Bureau Center for Economic Studies Paper No. CES-WP-10-29

Dye R (1985) Optimal length of labor contracts. Int Econ Rev 26(1): 251-270

Etchemendy S (2001) Constructing reform coalitions: the politics of compensations in Argentina's economic liberalization. Latin Am Polit Soc 43: 1-36

Ferreira PC, Rossi JL (2003) New evidence on trade liberalization and productivity growth. Int Econ Rev 44: 1383-1405

Freeman R, Medoff J (1984) What do unions do? Basic Books, Inc., New York

Galiani S, Lamarche C, Porto A, Sosa-Escudero W (2005) Persistence and regional disparities in unemployment (Argentina, 1980-1997). Reg Sci Urban Econ 35: 375-394

Galiani S, Sturzenegger F (2008) The impact of privatization on the earnings of restructured workers: evidence from the oil industry. J Labor Res 29(2): 162-176

Grout PA (1984) Investment and wages in the absence of binding contracts: a Nash bargaining approach. Econometrica 52(2): 449-460

Groves T, Hong Y, McMillan J, Naughton B (1994) Autonomy and incentives in Chinese state enterprises. Q J Econ 109(1): 183-209

Harding M, Lamarche C (2009) A quantile regression approach for estimating panel data models using instrumental variables. Econ Lett 104: 133-135

Haucap J, Wey C (2002) Structures and firms' incentives for productivity enhancing investments. WZB Discussion Paper FS IV 02Ü10. Wissenschaftszentrum, Berlin

Haucap J, Wey C (2004) Unionisation structures and innovation incentives. Econ J 114(494): C149-C165 
Holmes T, Schmitz J (1995) Resistance to new technology and trade between areas. Federal Reserv Bank Minneap Q Rev Winter: 2-18

Holmstrom B, Milgrom P (1994) The firm as an incentive system. Am Econ Rev 84(4): 972-991

Hsiao C (2003) Analysis of panel data, 2nd edn. Cambridge University Press, New York

Hsieh C-T, Klenow PJ (2009) Misallocation and Manufacturing TFP in China and India. Q J Econ 124(4): 1403-1448

Ichniowski C, Shaw K, Prennushi G (1997) The effects of human resource management practices on productivity: a study of steel finishing lines. Am Econ Rev 87(3): 291-313

Koenker R (2004) Quantile Regression for Longitudinal Data. J Multivariate Anal 91: 74-89

Koenker R (2005) Quantile regression. Cambridge University Press

Lamarche C (2008) Private school vouchers and student achievement: a fixed effects quantile regression evaluation. Labour Econ 15: 575-590

Lamarche C (2010) Robust penalized quantile regression estimation for panel data. J Econometrics 157: 396-408

Malcomson JM (1997) Contracts, hold-up, and labour markets. J Econ Lit 35: 1916-1957

Milgrom P, Roberts J (1990) The economics of modern manufacturing. Am Econ Rev 80(3): 511-528

Murillo MV (1997) La Adaptación del Sindicalismo Argentino a las Reformas de Mercado durante la Primera Presidencia de Menem. Desarrollo Económico 37(147)

Murphy KJ (1992) Determinants of contract duration in collective bargaining agreements. Ind Labor Relat Rev 45(2): $352-365$

O'Connell LD (1999) Collective Bargaining Systems in 6 Latin American Countries: Degrees of Autonomy and Decentralization, WP No. 399 Inter-American Development Bank, Washington D.C.

Parente S, Prescott E (1999) Monopoly rights: a barrier to riches. Am Econ Rev 89: 1216-1233

Parente S, Prescott E (2000) Barrier to riches. MIT Press

Prescott E (1998) Needed: a theory of total factor productivity. Int Econ Rev 39(3): 525-551

Stiroh KJ (2002) Information technology and the U.S. productivity revival: what do the industry data say? Am Econ Rev 92(5): 1559-1576

Stock JH, Watson MW (2008) Heteroskedasticity-robust standard errors for fixed effects panel data regression. Econometrica 76: 155-174

Tuman JP, Morris JT (1998) The transformation of the Latin American Automobile Industry. In: Tuman JP, Morris JT (eds) Transforming the Latin American Automobile Industry: Unions, Workers, and the Politics of Restructuring. M.E. Sharpe, New York

Ulph A, Ulph D (1994) Labour markets and innovation: ex-post bargaining. Eur Econ Rev 38(1): 195-210

Ulph A, Ulph D (2001) Strategic innovation with complete and incomplete labour market contracts. Scand J Econ 103: $265-282$

10.1186/2193-9020-2-11

Cite this article as: Lamarche: Industry-wide work rules and productivity: evidence from Argentine union contract data. IZA Journal of Labor \& Development 2013, 2:11

\section{Submit your manuscript to a SpringerOpen ${ }^{\circ}$ journal and benefit from:}

- Convenient online submission

- Rigorous peer review

- Immediate publication on acceptance

- Open access: articles freely available online

- High visibility within the field

- Retaining the copyright to your article

Submit your next manuscript at $\gg$ springeropen.com 